\title{
Establishment and life history characteristics of the southern South American mistletoe Misodendrum punctulatum (Misodendraceae)
}

\author{
Características del establecimiento e historia de vida de Misodendrum punctulatum \\ (Misodendraceae), un muérdago de Sudamérica austral
}

NORLAN TERCERO-BUCARDO* \& THOMAS KITZBERGER

Laboratorio Ecotono, CRUB, Universidad Nacional del Comahue, Quintral 1250, 8400 Bariloche, Argentina; e-mail: ntercero@crub.uncoma.edu.ar

\begin{abstract}
Taking advantage of host annual ring formation and synchronic embedding of the mistletoe haustorial system within the host xylem, we analyzed age-dependent life history traits and establishment conditions of Misodendrum punctulatum (Misodendraceae) infecting two deciduous species of Nothofagus in northern Patagonia, Argentina. Absolute determination of infection ages was performed by examining the number of host tree rings traversed by deepest haustoria in slices/cross-sections of parasitized branches/main trunks. Concomitantly, the number of branching events and basal stem diameters were taken from emerging aerial parts of the mistletoes. Host rings preceding the infection were used to determine branch trunk ages during infection. Relationships between haustorial and aerial age indices indicate that: (1) branching events are good non-destructive estimators of mistletoe age while basal diameters were poor estimators of age, (2) early development of $M$. punctulatum includes a multiyear holotrophic incubation period before producing aerial shoots, (3) the incubation period span is site and/or specie dependent being longer (4-6 yr) on the subalpine Nothofagus pumilio, and shorter (2 yr) on the lower altitude shrub $N$. antarctica, (4) Mistletoes infecting subalpine trees of Nothofagus pumilio in the harsher sites grew slower and were longer-lived than mistletoes infecting lower altitude shrubs of $N$. antarctica. M. punctulatum infected only young host branches $(<4 \mathrm{yr})$ suggesting strong limitations of mechanically penetrating thicker bark. When M. punctulatum shoots were present on Nothofagus trunks, absolute aging of haustorial systems in cross-sections revealed non-vegetative infections when trees were saplings. Multiple discrete events of renewal of the endophytic system spanning each about $24 \mathrm{yr}$ are probably related to the maintenance of appropriate connections with functional host xylem.
\end{abstract}

Key words: endophytic system, establishment, Misodendrum, mistletoes, annual tree rings, Nothofagus.

\section{RESUMEN}

Aprovechando la formación de anillos anuales de crecimiento en los hospedadores y que el sistema haustorial de los muérdagos va quedando sincrónicamente embebido en el xilema del hospedador, analizamos características edad dependientes de la historia de vida y del establecimiento de Misodendrum punctulatum cuando infecta a dos especies deciduas de Nothofagus en el noroeste de la Patagonia, Argentina. La determinación de la edad de establecimiento de las infecciones fue realizada examinando el número de anillos anuales de crecimiento del hospedador, en cortes transversales de ramas o troncos principales de Nothofagus, atravesados por el haustorio más profundo. Concomitantemente, se registró el número de eventos anuales de crecimiento (índice de edad aérea) y el diámetro basal de los tallos de los muérdagos. Los anillos de crecimiento de los hospedadores precedentes al establecimiento de los muérdagos fueron usados para determinar la edad de las ramas o troncos principales al ser infectados. La relación entre la edad haustorial y el índice de edad aérea indican que: (1) el recuento de los eventos de crecimiento de los tallos es un método no destructivo adecuado para estimar la edad de este muérdago, mientras que el diámetro basal es un método menos eficiente, (2) al inicio del desarrollo M. punctulatum presenta un período de incubación holotrófico, de varios años, antes de producir estructuras aéreas, (3) la duración del período de incubación es sitio y/u hospedador dependiente siendo más extenso (4 a 6 años) en bosques subalpinos de Nothofagus pumilio y más corto (2 años) en matorrales de $N$. antarctica en bajas altitudes, (4) cuando los muérdagos viven en bosques subalpinos de Nothofagus pumilio en sitios desfavorables crecen más lento y son más longevos que cuando están en matorrales de $N$. antarctica en bajas altitudes. Misodendrum punctulatum infecta principalmente ramas jóvenes $(<4$ años $)$ sugiriendo una fuerte limitación mecánica del haustorio para penetrar cortezas de 
mayor espesor. Cuando se observaron infecciones de M. punctulatum en los troncos principales de Nothofagus y se analizaron, la edad total del sistema haustorial no reveló infecciones vegetativas (invasión sistémica) durante la etapa juvenil de los hospedadores. Múltiples y discretos eventos de renovación del sistema endofítico, con una duración de aproximadamente 24 años cada uno, posiblemente estén relacionados con el mantenimiento de una conexión apropiada con el xilema funcional del hospedador.

Palabras clave: endophytic system, establishment, Misodendrum, mistletoes, annual tree rings, Nothofagus.

\section{INTRODUCTION}

Unlike free-living plants, mistletoes need to colonize and establish on specific biotic substrates (Reid et al. 1995, Sargent 1995). Once established, mistletoes become relatively independent of abiotic resource supply by means of partial physiological dependence on host resources (Elheringer et al. 1985). This trade-off may be responsible in shaping lifehistories characteristics in many hemiparasitic plants.

After release from parent plants, mistletoe seeds must arrive, stick or anchor to the host branch and germinate by means of their own seed reserves. A brief autotrophic free-living phase between germination and infection follows in which modified hypocotyls grow, adhere, penetrate the host bark and generate a haustorial meristem within the host cambium (Calvin 1967). During this stage the mistletoe is mostly dependent on host resources (Lamont 1983). In some mistletoes aerial shoot development begins immediately after infection quickly resuming into a semi-autotrophic phase (Lichter \& Berry 1991). In other mistletoes, however, the remains of the radicle and hypocotyl die and the development of aerial shoots from endophytic portions is delayed. Developing this way a holotrophic phase in which infections are not visible (incubation period, sensu; Scharpf \& Parmeter 1982).

To date, a multiyear incubation period has been detected in only one genus within the Viscaceae (Arceuthobium, Calvin \& Wilson 1996) but it may possibly have been overlooked in other hemiparasites. Delaying aerial shoot emergence after germination is not possible in free-living plants as seed reserves are limited. Thus, most terrestrial plants are exposed to high mortality rates during early establishment due to insufficient resource supply caused by underdeveloped resource gathering structures (Harper 1977). Instead, steady carbon supply from the host may allow hemiparsites to develop large enough endophytic systems to cope with the resource demand once the plant adopts its aerial hemiparasitic phase.
Another important aspect that differentiates hemiparasites from free-living plants is that substrates (hosts) have a limited longevity/ functionality in the former and unlimited in space and time in the latter group. Even if secondary or vegetative reinfections are possible, longevity of individual hemiparasites is constrained by the longevity or functional duration of the host or host structure they depend on. For instance, parasites infecting herbaceous plants are shorter lived than mistletoes infecting woody plants and mistletoes infecting or vegetatively colonizing main stems may potentially be more long-lived than those locally infecting only branches. Mistletoes die with the host or host structure (e.g., branch breakage, whole individual death; Kelly et al. 1997). Alternatively, when the endophytic connection supply can no longer sustain demand of resources an individual infection may die or vegetatively reinfect new functional portions of the host (Agrios 1969, Manion 1991, Reid et al. 1995). An examination of the timing and conditions necessary for the development of these stages can help to understand better the environmental and host constraints as well as aspects of the dynamics of infections by parasitic vascular plants.

Analysis of host annual rings at the point where they synchronically embed the haustorial system of the mistletoe is a useful tool for retrospectively analyzing developmental, demographic, and life history aspects of hemiparasites (Srivastava \& Esau 1961, Calvin 1967, Dawson et al. 1990). Absolute tree-ring dates in combination with morphological/ developmental data provide unique insights to understand age-dependent processes that otherwise would only emerge from long-term monitoring studies. In addition the technique provides unique opportunities to validate nondestructive aging indices such as bifurcate branching patterns and other morphometric variables (Norton et al. 1997).

In this paper, we make use of annual tree rings in Nothofagus branches and crosssections to analyze establishment, development, and life history characteristics of 
the southern South American mistletoe, Misodendrum punctulatum, infecting two deciduous species in northern Patagonia, a tree (N. pumilio) and a shrub ( $N$. antarctica). Specifically we aimed to: (1) establish the existence and length of an incubation period and determine temporal variation among hosts species or sites relating haustorial ages (anatomical aging) with aerial mistletoe structure (stem branching patterns), (2) evaluate host branch ages most frequently infected by $M$. punctulatum, (3) compare the longevity of infections on branches with infection on main host trunk and (4) assess by aging and sexing mistletoes the maximum longevity, stem growth rates and age of first reproduction of $M$. punctulatum.

\section{MATERIALS AND METHODS}

\section{Study species and host populations}

Misodendrum punctulatum Banks ex DC. (Misodendraceae) is a dioecious hemiparasitic small shrub in a monotypic family endemic to southern South America. This family comprises 10 species that specifically infect species of the genus Nothofagus over its geographic range $\left(33^{\circ}\right.$ to $56^{\circ} \mathrm{S}$, Orfila 1976, Rossow 1982). Unlike most mistletoes that are bird dispersed (Calder 1983); mammal (Amico \& Aizen 2000), ballistics and epizoochory (Hawksworth 1961, Agrios 1969, Hawksworth \& Wiens 1996, Restrepo et al. 2002) or wind dispersed are particular cases (Orfila 1978). Misodendrum is the only wind-dispersed hemiparasitic genus. Fruits are small achenes bearing three up to 8.5 $\mathrm{cm}$-long hairy bristles ( $1 \mathrm{~cm}$ for M. punctulatum; Orfila 1976) that fly and passively entangle around small branches and stems. $M$. punctulatum is the most abundant mistletoe in the Patagonian forests and can heavily infect two deciduous (Nothofagus pumilio (Poepp. et Endl.) Krasser and Nothofagus antarctica (Forst.) Oerst) and two evergreen tree species (Nothofagus dombeyi (Mirb.) Oerst. and Nothofagus betuloides (Mirb.) Oerst., Orfila 1976, 1978). Sympodially growing branches (Orfila 1976, 1978) possess reduced photosynthetic tissue in reduced scale-like leaves. After dispersal, entangled seeds germinate, a recurved hypocotyl protrudes, and a sticky holdfast adheres to the host branch. After infection, the early wood is invaded by haustoria, producing the characteristic host branch/stem swelling and triangle-shaped endophytic structures. In main host trunks, endophytic structures can reach up to 7 to $8 \mathrm{~cm}$ after which the mistletoe dies or laterally rejuvenates producing characteristic scars (Cwielong \& Rachenberg 1995). M. punctulatum flowers during the spring (late September to early November). Achenes mature over the summer, dispersion occurs in late January to February and seeds germinate during the following spring (Tercero-Bucardo 2001).

In this study we focused on the relations between $M$. punctulatum with two deciduous hosts species: $N$. antarctica and $N$. pumilio. Nothofagus antarctica occurs as a well-formed tree 10 to $15 \mathrm{~m}$ tall on optimal sites, as a small shrub $(<1 \mathrm{~m}$ tall) in bogs, and a shrubby tree $(2$ to $3 \mathrm{~m}$ tall) on rocky, xeric and exposed sites. It rarely attains ages greater than $200 \mathrm{yr}$ and at ages of 80 to $120 \mathrm{yr}$ often exhibits sings of senescence. Nothofagus pumilio is a 20 to $25 \mathrm{~m}$ tall tree that can live more than $350 \mathrm{yrs}$ (LaMarche et al. 1979) that in the sites of study occurs only in the sub alpine zone and commonly forms the upper tree limit (Veblen et al.1996).

During the spring of 1999 and 2000, we sampled three populations in Nahuel Huapi National Park, Argentina. One population was a ca. 2 to $5 \mathrm{~m}$ tall $N$. antarctica shrubland at

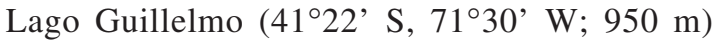
and two populations were in 15 to $20 \mathrm{~m}$ tall $N$. pumilio subalpine forests at Chall Huaco ( $41^{\circ} 14^{\prime} \mathrm{S}, 71^{\circ} 19^{\prime} \mathrm{W} ; 1,200 \mathrm{~m}$ ), and Cerro Otto $\left(41^{\circ} 09^{\prime} \mathrm{S}, 71^{\circ} 22^{\prime} \mathrm{W} ; 1,100 \mathrm{~m}\right)$. All the populations sampled correspond to continuous habitats slightly-disturbed.

\section{Aging of Misodendrum punctulatum infections on branches}

Sampling was performed by randomly laying out in each site three or four $50 \mathrm{~m}$-long transects. At stations located every $10 \mathrm{~m}$ along each transect we collected the four nearest samples (host branches infected) in each quadrant, sampling from all heights, until completing 60 or 80 samples per site. A sample consisted of a ca. $3 \mathrm{~cm}$-long Nothofagus branch segment centered at the attachment point of an infection by $M$. punctulatum as well as the entire mistletoe. Mistletoe sizes ranged from less that $1 \mathrm{~cm}$-long protruding shoots to mature individuals (20 cm long). Specimens were also collected where no aerial shoots of the mistletoe were present, but the characteristic branch swelling was visible indicating the presence of a young infection. A total of 200 samples, 80 of $N$. antarctica and 120 of $N$. pumilio were collected. 
Host branch samples were processed following Dawson et al. (1990). Samples were immersed in $60 \%$ ethanol for a minimum of 48 $\mathrm{h}$ before sectioning in 20 to $80 \mu \mathrm{m}$ slices. A total of 100 branch slices from the junction between the mistletoe and the host were obtained for each sample and preserved in glycerin to avoid desiccation. The 25 best sections were stained and observed under light microscopy (Bausch \& Lomb, Austria) at x100 or $\mathrm{x} 400$. Dendrocronological studies in South America have long confirmed that growth rings in Nothofagus are annually formed (Schulman 1956, Lamarche 1979). The age of establishment was determined by counting the maximum number of Nothofagus growth rings traversed by the projection of the longest visible haustorium (sinkers, Fig. 1). The

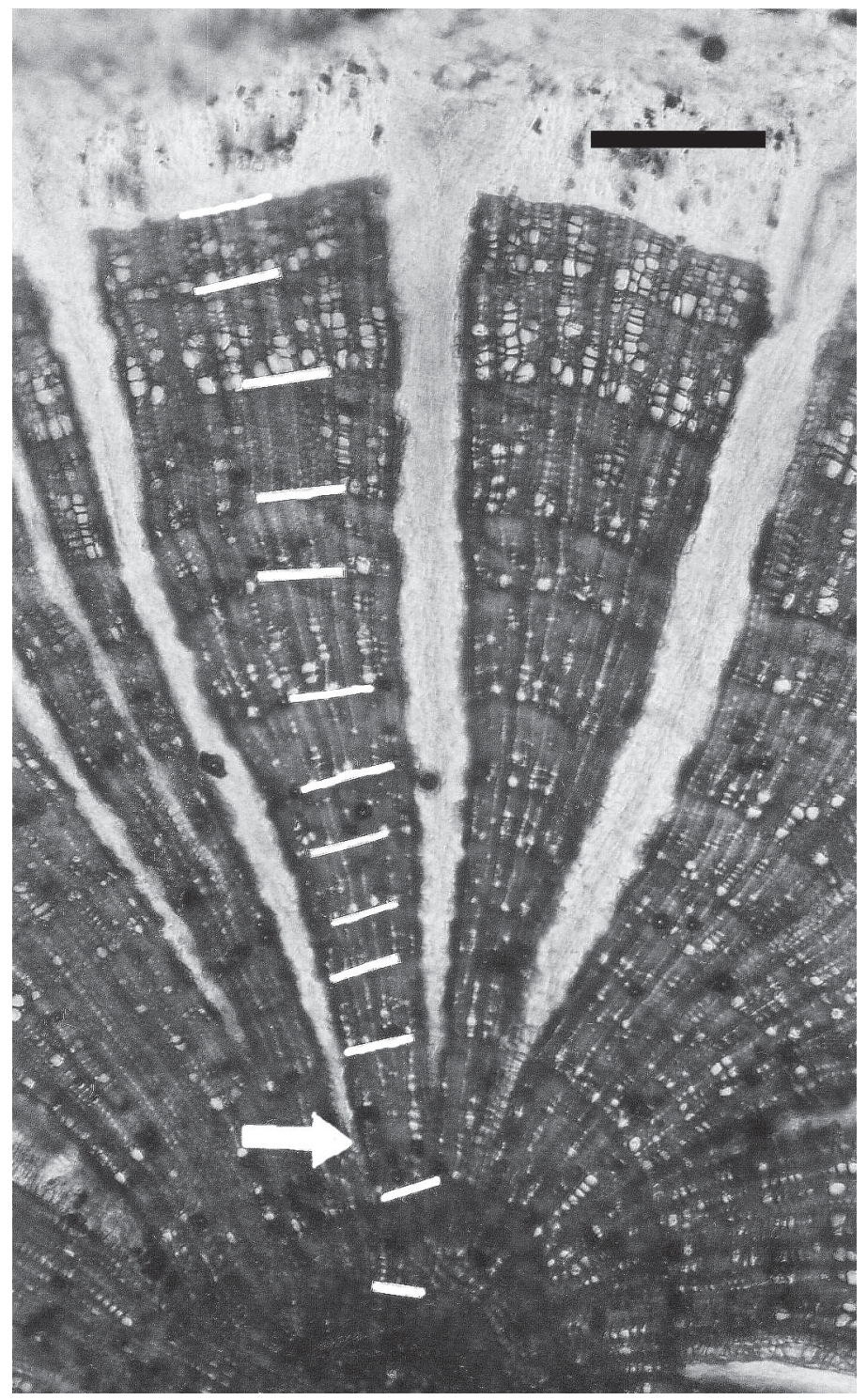

Fig. 1: Transversal section of a Nothofagus pumilio branch on the mistletoe-host junction. Note the annual host tree rings (indicated by white lines) and the mistletoe endophytic "sinkers" embedded in the host xylem at different depths. The white arrow indicates the deepest sinkers used to estimate the mistletoe total age. $\mathrm{Bar}=500 \mu \mathrm{m}$.

Sección transversal de una rama de Nothofagus pumilio cortada en el punto de unión muérdago-hospedador. Note los anillos anuales del hospedador (indicados por líneas blancas) y el haustorio del muérdago embebidos en el xilema del hospedador a diferentes profundidades. La flecha blanca indica la proyección haustorial más profunda usada para estimar la edad total del muérdago. La barra negra $=500 \mu \mathrm{m}$. 
longest sinker is the oldest and provides a way to age each infection (Srivastava \& Esau 1961). Sinkers do not grow intrusively within the host xylem. Instead, once the parasite has penetrated the host phloem, it establishes a meristematic region at the junctions of the host plant vascular cambium and the host xylem. Subsequent growth of the sinkers occurs in a radially eccentric way in synchrony with the meristematic activity of the host vascular cambium, so that the sinker eventually becomes embedded in the host xylem (Calvin 1967).

When aerial parts of the mistletoes were present, we counted the total number of branching events along the longest stem (Fig. 2), measured the mistletoe stem basal diameter with caliper, recorded the presence/absence of reproductive organs, and sexed the individuals. We sexed individuals to determine possible differences in age of first reproduction.

The number of branching events and the basal diameters were regressed on the haustorium age. This morphological age index was validated by testing if the slope of linear regressions between the anatomical and the number of branching events departed significantly from a 1:1 ratio. Assuming no error in the anatomical haustorium age determination, an accurate age index should have a slope near one when regressing it against the number of branching events. An intercept of zero indicates immediate emergence of aerial parts, while intercepts less than zero suggest the existence of a period after establishment without stems (incubation period). The regression analysis model of the mistletoe-basal diameter on haustorial age also provides information on the annual grow rate of the mistletoes.

In October of 2000 an extensive sampling of $M$. punctulatum was performed in two $N$. antarctica shrublands to describe age structures and determine critical life history traits such as maximum longevity and age of first reproduction. In each stand we censused all mistletoes in 30 host trees recording reproductive maturity, sex, and age from each mistletoe observed for a total of 873 individuals. Age was determined using the total number of branching events of the mistletoe stem. The aerial age of the infections was corrected adding 2 yr to compensate time without produce aerial shoot (see first section of results).

\section{Age-dependent susceptibility to infection}

The age of the host branches when infection occurred was determined by subtracting the haustorium age from the total branch age (i.e., the number of annual growth rings formed before the infection occurred). Age distributions were used to determine the age range more susceptible to infection by M. punctulatum.

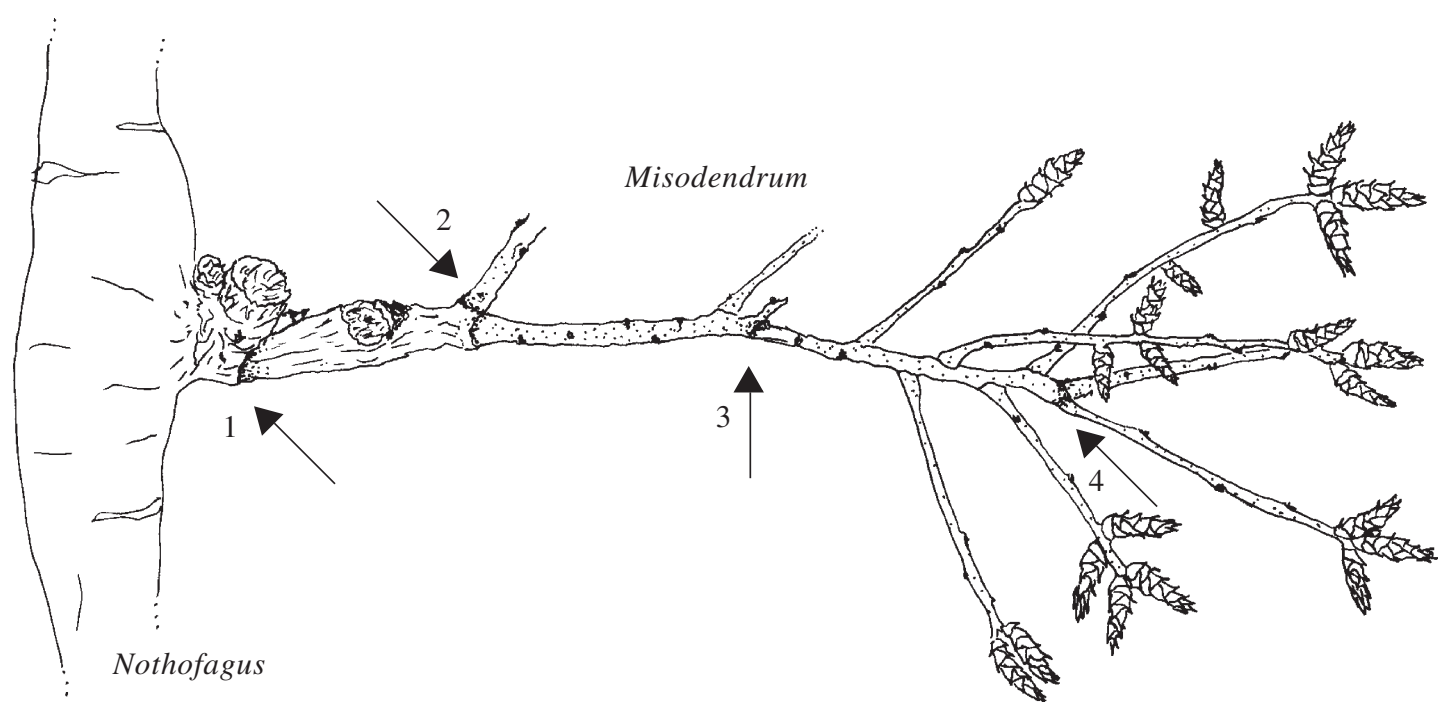

Fig. 2: Diagram of stem structure in Misodendrum punctulatum attached to a Nothofagus branch. Successive numbers indicate segments of increasing age. The stem illustrated is $4 \mathrm{yr}$ old (the actual infection may be older due to the incubation period).

Diagrama del tallo de un individuo de Misodendrum punctulatum infectando Nothofagus. Los números sucesivos indican segmentos de incremento de edad. El tallo ilustrado tiene 4 años de edad (la infección actual puede tener más de 4 años debido al periodo de incubación). 
Morphology and aging Misodendrum punctulatum infections on stems

Samples were collected from two infected $N$. pumilio trees that showed $M$. punctulatum aerial parts emerging from the main trunk. Transversal stem cross-sections were cut with a chainsaw at $3 \mathrm{~cm}$ intervals including the base of the infection. Sections were sanded to render visible under stereoscopic microscope the endophytic systems and the host annual rings and scarring morphology (Fig. 6). We recorded the age of first establishment by assuming that establishment occurred during the formation of the host ring that embedded the deepest haustorium. We recorded the number of endophytic (triangular-shaped) structures per cross-section, the duration of each endophytic infection and the age when systemic infections occurred. The length of each infection event was determined by the number of tree rings traversed by the endophytic system, from the deepest extreme of the haustorial projections until the more external callus-forming host tree ring. As events of infection were anatomically connected, we discarded the possibility that the different events of infection were produced by new infections from seeds.

\section{RESULTS}

\section{Anatomical haustorium age versus number of branching events}

The number of growth pulses (visible as branching events) along the M. punctulatum stem was significantly related to the age of the deepest haustorium, in shrubland of $N$. antarctica $\mathrm{y}=-$ $1.692+1.016 \mathrm{x}, \mathrm{r}^{2}=0.90$ at $\mathrm{LG}$; in subalpine forest of $N$. pumilio $\mathrm{y}=-4.326+0.895 \mathrm{x}, \mathrm{r}^{2}=0.70$ at $\mathrm{CH}$, and $\mathrm{y}=-3.807+0.883 \mathrm{x}, \mathrm{r}^{2}=0.80$ at $\mathrm{CO}$ (Fig. 3). In all three populations, the slopes did not differ significantly from one, demonstrating that the number of branching events is a reliable index of age particularly when infecting $N$. antarctica. However, in all three populations the intercepts differed significantly from zero suggesting the existence of a multiyear incubation period. When the host was $N$. antarctica the $\mathrm{x}-$ axis intercept (i.e., the hypothetical age of shoot emergence) was $1.7 \mathrm{yr}$ (95\% CI: 1.0-2.2 yr). On $N$. pumilio, x-axis intercepts were 4.8 yr $(95 \%$ CI: 3.2-6.0 yr) and $4.2 \mathrm{yr}$ (95\% CI: 3.3-5.1 yr) at $\mathrm{CH}$ and $\mathrm{CO}$, respectively. In addition, four swollen shootless $N$. pumilio branch cuttings had maximum haustorium ages of 4 and $6 \mathrm{yr}$ (Fig. 3C).
In contrast, the basal diameter of $M$. punctulatum proved to be a poor predictor of age as indicated by weak fits in the linear regression models $\mathrm{y}=-2.498+0.980 \mathrm{x}, \mathrm{r}^{2}=$ 0.64 at $\mathrm{LG}$ for $N$. antarctica; $\mathrm{y}=-1.730+$ $0.490 \mathrm{x}, \mathrm{r}^{2}=0.36$ for $N$. pumilio at $\mathrm{CH}$, and $\mathrm{y}=$ $-0.956+0.360 \mathrm{x}, \mathrm{r}^{2}=0.40$ at CO. The smallest visible mistletoes corresponded to infections $\geq$ 3 and $>4 \mathrm{yr}$ when host were $N$. antarctica and $N$. pumilio, respectively. Slopes in regression model shown above suggest that the radial growth rate of mistletoes stems growing on $N$. antarctica $(0.98)$ is c. two times higher than growth on N. pumilio (0.49).

Anatomically and morphologically aging a large number of $M$. punctulatum plants (Figs. 3 and 4), allowed us to determine a set of life history attributes. Misodendrum punctulatum attained reproductive age at 3-4 and 4-5 yr of age for males and females, respectively (Fig. 4) and was shorter-lived (maximum age $13 \mathrm{yr}$ ) when growing on the shrub $N$. antarctica (Figs. $3 \mathrm{~A}, 4 \mathrm{C}$ ) than on $N$. pumilio trees (maximum age 20 yr, Fig. 3C).

\section{Age-dependent susceptibility to infection}

The distribution of host branch ages at the moment of infection suggests that susceptibility to infection rapidly declines with branch age (Fig. 5). However, the rate of this decline was site and/ or host specific. One-year-old branches accounted for 28 and $18 \%$, and 1 to 4 yr old branches accounted for 86 and $60 \%$ of the infections of low elevations shrubland of $N$. antarctica and subalpines forest of $N$. pumilio, respectively. Maximum ages at which branches were infected were 7 and $15 \mathrm{yr}$ for low elevations shrubland of $N$. antarctica and subalpines forest of $N$. pumilio, respectively (Fig. 5).

\section{Morphology and aging M. punctulatum infections on stems}

Misodendrum punctulatum infections generally occurred on the youngest branches. However, it was relatively common to observe mistletoes emerging from the host main trunk. The morphology of endophytic systems as observable by transversal cuts indicates that these infections were not the result of lateral long-distance expansion of branch infections common in other mistletoes, but rather of a new establishment from seeds when the tree was a sapling followed by several events of rejuvenation of the endophytic system (Fig. 6). At a DBH of $30 \mathrm{~cm} \mathrm{~N}$. pumilio, transversal cut indicated that the infection lasted $75 \mathrm{yr}$ by 
means of three successive events of endophytic system formation (Fig. 6 top). A second sample at a $\mathrm{DBH}$ of $18 \mathrm{~cm}$ showed that the primary infection occurred when the bole was 8 yr old, ca. a DBH $1 \mathrm{~cm}$ (Fig. 6 bottom). Successive events of endophytic system formation, death,
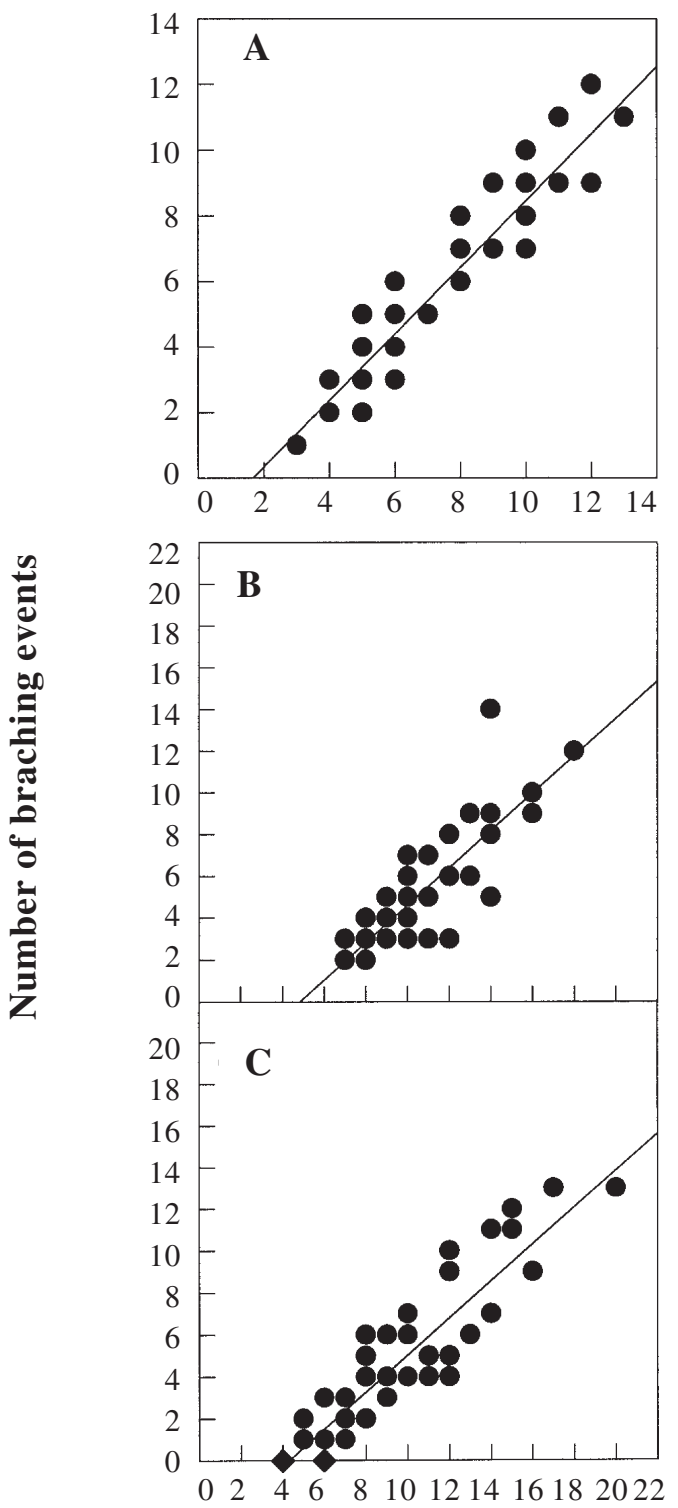

\section{Age of the deepest sinkers (years)}

Fig. 3: Linear regression of the age obtained counting the stem annual growth pulses of the mistletoes versus age determined by the number of host annual tree rings traversed by the deepest sinker. (A) in a shrubland of $N$. antarctica at LG y $=-1.692+1.016 \mathrm{x}, \mathrm{r}^{2}=0.90, \mathrm{n}=74$; (B) in subalpine forest of $N$. pumilio at $\mathrm{CH} \mathrm{y}=-4.326+0.895 \mathrm{x}, \mathrm{r}^{2}=0.70, \mathrm{n}=50$; and (C) in subalpine forest of $N$. pumilio at $\mathrm{CO} \mathrm{y}=-3.807+0.883 \mathrm{x}, \mathrm{r}^{2}=0.80, \mathrm{n}=60$. The diamond symbols in lower panel indicate swelled infections without aerial shoots.

Regresión lineal de la edad obtenida contando los eventos anuales de crecimiento de los tallos del muérdago versus la edad determinada por recuento del número de anillos del hospedador atravesados por el haustorio más profundo. (A) en matorrales de baja altura de $N$. antarctica en LG y $=-1,692+1,016 \mathrm{x}, \mathrm{r}^{2}=0,90, \mathrm{n}=74 ;$ (B) en bosques subalpinos de $N$. pumilio en $\mathrm{CH}$ y $=-4,326+0.895 \mathrm{x}, \mathrm{r}^{2}=0,70, \mathrm{n}=50 ; \mathrm{y}(\mathrm{C})$ en bosques subalpinos de $N$. pumilio en $\mathrm{CO} \mathrm{y}=-3,807+0,883 \mathrm{x}, \mathrm{r}^{2}=0,80$, $\mathrm{n}=60$. Los símbolos romboidales del panel inferior indican infecciones aún sin producir estructuras aéreas. 


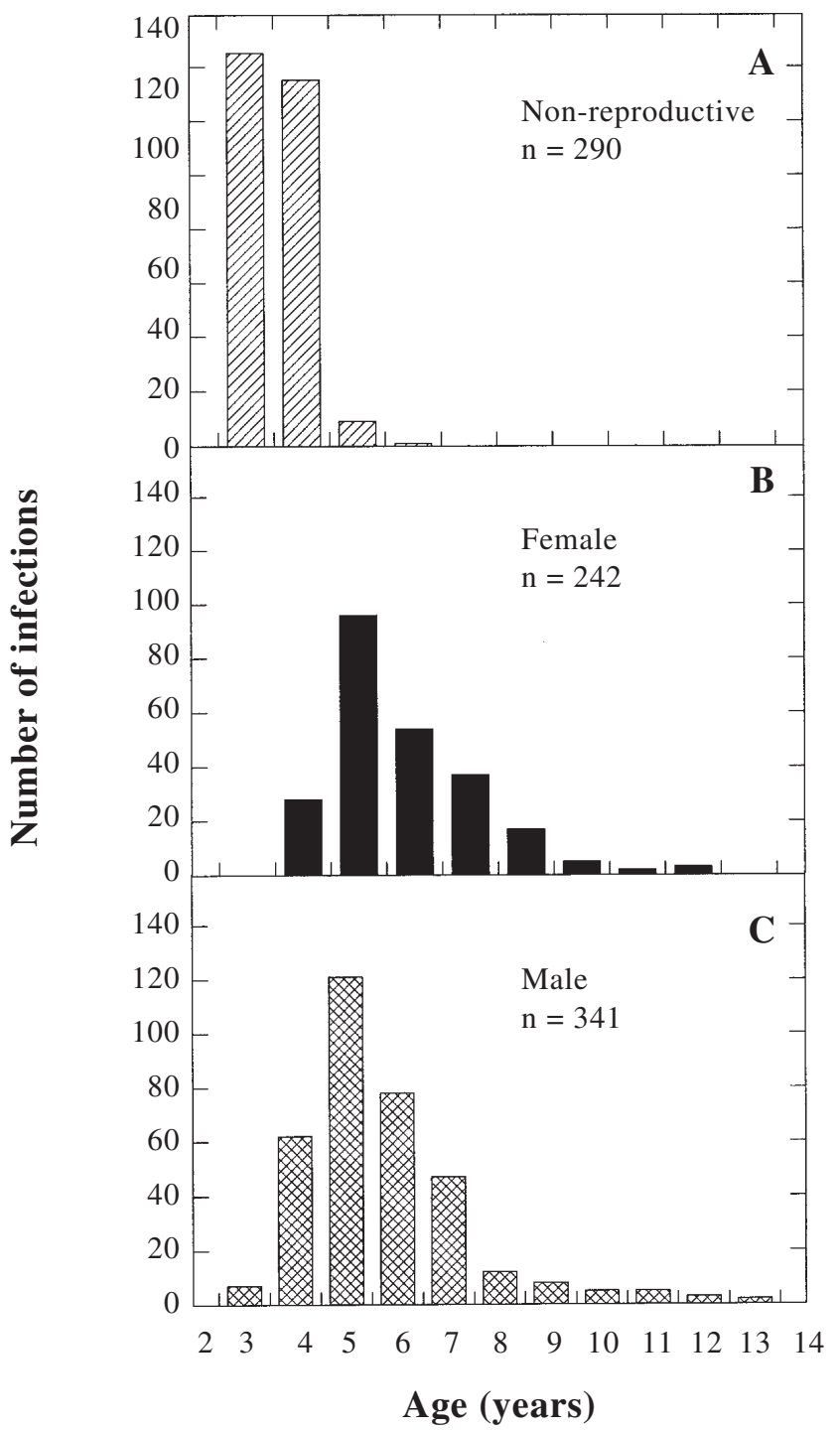

Fig. 4: Age distribution of non-reproductive (A), female (B) and male (C) M. punctulatum growing on shrublands of $N$. antarctica. Ages are based on aerial morphology (branching events) corrected by the duration of the incubation period.

Distribución de edades de $M$. punctulatum no reproductivos (A), hembras (B) y machos (C) infectando matorrales de $N$. antarctica. Las edades se basan en el conteo del número de eventos anuales de crecimiento del tallo corregidas por la duración del periodo de incubación.

and re-infection allowed the mistletoe to survive at the time of sample extraction $102 \mathrm{yr}$ after infection (Fig. 6). The average longevity of each event of endophytic system formation was of $24 \mathrm{yr}$ in the samples analyzed. Host reaction to vegetative rejuvenation in trunks consists of the formation of a callus similar to the scars formed after other injuries (Fig. 6). This callus generally covered completely the dead endophytic system within 15 to $20 \mathrm{yr}$.

\section{DISCUSSION}

Incubation period in Misodendrum punctulatum

We report here another mistletoe that develops a multiyear holotrophic phase of delayed shoot emergence after initial infection or incubation period (Wagener 1962, Scharpf \& Parmeter 1982). Unlike other authors who have detected incubation periods by following mistletoe 


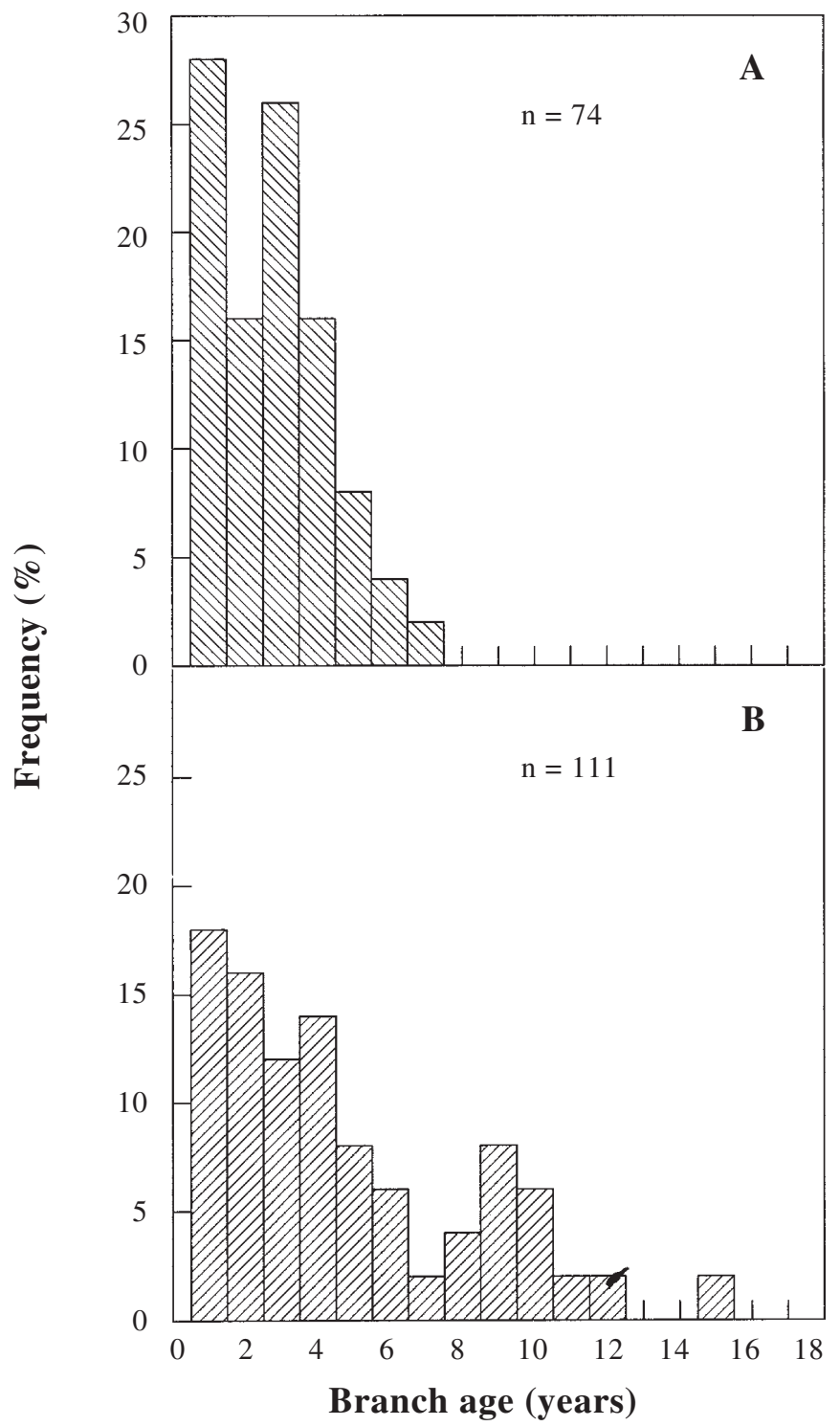

Fig. 5: Host branchs distributions of ages at infection on shrubland of N. antarctica (A) and subalpine forests of $N$. pumilio (B). Data were obtained by subtracting the mistletoe anatomical age (number of host tree ring traversed by the mistletoe deepest sinker) from the branch total tree-ring age.

Distribución de edad de las ramas de los hospedadores al momento de ser infectadas en matorrales de $N$. antarctica (A) y en bosques subalpinos de $N$. pumilio (B). Estos datos fueron obtenidos restando la edad de los muérdagos (número de anillos anuales de crecimiento de los hospedadores atravesados por el haustorio más profundo) de la edad total de la rama (número total de anillos anuales de crecimiento).

emergence over time (Wagener 1962, Scharpf \& Parmeter 1982), this study is the first in documenting and describing the length of incubation period and its possible environmental variability based on inferential haustorium versus shoot-based age data. Dawson et al. (1990), performing similar analyses on Phoradendron juniperinum, did not detect any delays between infection and aerial shoot production.
Incubation phases differed between sites, being shorter and more constant $(2 \mathrm{yr})$ in the lower elevation, thermically more favorable $N$. antarctica habitat, and longer and more variable ( 4 to $6 \mathrm{yr}$ ) in the higher elevation, hasher subalpine habitat of $N$. pumilio. Given that the endophytic host-mistletoe connection develops as a function of coordinated growth of host and mistletoe xylem, it is likely that endophytic systems may become fully 


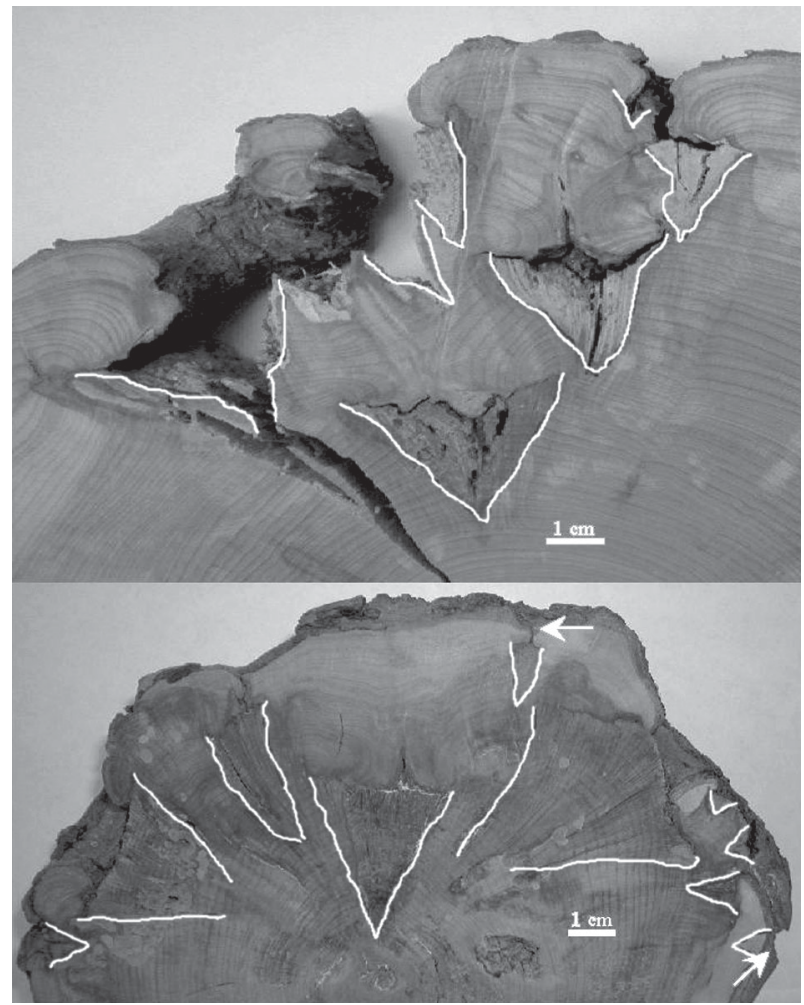

Fig. 6: Transverse section of a $30 \mathrm{~cm}$ (top) and an $18 \mathrm{~cm}$ (bottom) diameter trunk of Nothofagus pumilio infected by Misodendrum punctulatum. White lines encircle areas with endophytic tissue. The arrows in the lower panel indicates the point of insertion of the current mistletoe shoot.

Sección transversal de un tronco de Nothofagus pumilio de $30 \mathrm{~cm}$ de diámetro (arriba) y otro de $18 \mathrm{~cm}$ (abajo) infectados por Misodendrum punctulatum. Las líneas blancas delimitan las áreas del xilema con tejido endofítico. Las flechas en el panel de abajo indican el punto donde se insertaban los últimos tallos del muérdago.

developed and hydraulically efficient earlier in faster-growing hosts from lower elevation sites than slower-growing subalpine trees. Yet, growth rate differences may also be due to intrinsic differences between host species. Scharpf \& Parmeter (1976) showed no differences in the length of incubation period when Arceuthobium abietinum was growing on red and white fir in the same area. However, site-dependent differences in length of incubation period were noted for this species growing on red fir in different areas (Scharpf \& Parmeter 1982). In British Columbia, half the infections of Arceuthobium tsugense produced shoots in the second year after infection and shoots were produced the following year; the incubation period extends from 3 to $6 \mathrm{yr}$ in Alaska (Shaw \& Loopstra 1991, Hawksworth \& Wiens 1996).

Reid et al. (1995) proposed that life history strategies of mistletoes could be explained by key environmental influences. They predicted that in stable habitats mistletoes should develop and grow rapidly, whereas in harsh, disturbance-prone habitats, mistletoe growth should be slow and resources diverted to ensure persistence (e.g., haustorial development). Along the same lines, we propose that long incubation phases may be positively selected in some host-mistletoe systems in harsh environments. A phase of delayed shoot emergence but active endophytic growth may provide mistletoes the appropriate timing to develop host-parasite xylem connections that are able to face high water demands once shoots emerge, thus avoiding the risk of high internal resistance at hydraulic bottlenecks such as the haustorial connection (Fischer 1983). Strikingly, both M. punctulatum and Arceuthobium have morphological traits such as leaves reduced to scales, long incubation periods, and well-developed endophytic systems that suggest their adaptation to harsh environments. Perhaps the most extreme advance towards a holoparasitic habit within the Santalales is observed in Tristerix aphyllus, a mistletoe of columnar desert cacti whose endophytic (almost 
non-autotroph) life history allow the mistletoe to escape hot, desiccating desert conditions (Martínez del Río et al.1996, Silva \& Martínez del Río 1996). Similarly, around 20 species of Pilostyles (Apodanthaceae) all parasitizing shrubs in subtropical and desert regions of North and South America, Africa and Middle East, emerge from the host stem only as reproductive structures (Willis 1973). More work is needed on patterns of variability in incubation period length along stress environmental gradients and among host trees that may increase our understanding of the selective advantage of this peculiar developmental stage.

Wind- and ballistically dispersed seeds are small $(2.5 \times 0.5 \mathrm{~mm} ; 0.3 \mathrm{mg}$ for Misodendrum, $2 \times 0.8 \mathrm{~mm}$ to $3.1 \times 1.5 \mathrm{~mm}$ for Arceuthobium; Hawksworth \& Wiens 1996), one to two orders of magnitude smaller than seed dispersed by endozoochory (Herrera 1987, Dawson \& Ehleringer 1991, Ladley \& Kelly 1996). Smallseeded mistletoes may be strongly limited in the upper branch size they can infect due to the reduced haustorial disks they can develop with such limited seed reserves. Abiotic dispersal of small seeds, on the other hand may involve no lower twig size limit because seeds are able to reach small branches and have a less damaging haustorial intrusion in the host branches. By infecting only very small branches, however, these mistletoes might have developed delayed shoot emergence on the basis of a temporary holotrophic phase (incubation period) in order to grow in synchrony and total nutrient dependence with the host twig until a haustorial connection capable of sustaining future nutrient demands is developed. This may be a possible explanation why incubation periods only occur in mistletoes such as $M$. punctulatum and species of Arceuthobium. However, we cannot assert that this phenomenon is bound particularly to abiotic seed dispersion syndrome. More work is necessary on the endophytic development of other species of Misodendrum and endozoochorous dispersed mistletoes in order to confirm this pattern.

\section{Age at first reproduction and longevity}

Similar ages of first reproduction that $M$. punctulatum have been found in other mistletoes: Arceuthobuim abietinum, 2 to $4 \mathrm{yr}$ (Scharpf \& Parmeter 1982), Amyema preissii and Lysiana exocarpi, 3 yr (Yan 1993).

Maximum longevity of infections on branches was variable between sites. Misodendrum punctulatum infections tended to be substantially shorter lived on the lower elevation $N$. antarctica shrubland than on the subalpine $N$. pumilio forest. This longevity is similar to that shown with anatomical techniques in other mistletoes of temperate areas: $19 \mathrm{yr}$ in Phoradendron juniperinum (Dawson et al. 1990), 22 yr in Alepis flavida, $17 \mathrm{yr}$ in Ileostylus micranthus and $10 \mathrm{yr}$ for Tupeia antarctica (Norton et al. 1997).

Mortality of mature mistletoes is frequently related to host and branch death (Scharpf \& Parmeter 1982, Reid et al. 1995, Ladley \& Kelly 1996). However, extreme climatic or disturbance events such as frosts, droughts or fire may cause the differential death of the mistletoe while hosts survive (Reid et al. 1995). During the severe 1999 spring and summer drought in northern Patagonia we observed extensive branch dieback in $N$. antarctica accompanied by the death of infecting $M$. punctulatum. However, branch death occurred independent of mistletoe infection (TerceroBurcardo 2001). Misodendrum punctulatum can also die before the branch dies. Cwielong \& Rajchenberg (1995) report that $90 \%$ of the $M$. punctulatum growing on $N$. pumilio branches $>$ $30 \mathrm{~mm}$ in diameter were dead or declining. In summary, $M$. punctulatum longevity on branches may be shortened by hydraulic or physical restrictions imposed by the branchmistletoe interaction, while the upper limit to longevity may be the result of hydraulic/ physical limitations of the mistletoe itself. In sum, the length of reproductive period is similar between sites as shorter-lived $M$. punctulatum on lower elevation shrubland of $N$. antarctica compensate with a shorter nonreproductive period by having shorter incubation and juvenile shoot phases.

\section{Branch susceptibility to infection}

The pattern of branches infected by $M$. punctulatum (youngest branches) resembles that of other ballistic and epizoochorous mistletoes such as Arceuthobium spp. whose seedlings infect branches of $<5$ yr old (Hawksworth \& Wiens 1996). In contrast, some bird-dispersed mistletoes show an optimal range of branch diameters of 10 to $14 \mathrm{~mm}$ and successful establishment on up to $40 \mathrm{~mm}$ thick branches (Sargent 1995). Likewise, a mammaldispersed loranthaceous mistletoe infects branches with mean diameters of $26 \mathrm{~mm}$ and successful establishment occurred on up to 90 $\mathrm{mm}$ wide host branches (Amico 2000). If seed mass limits the size of the haustorial disks, and its ability to penetrate bark (Dawson \& Ehleringer 1991), then there will be an upper 
limit in bark thickness and branch size beyond which seedlings will fail to reach the cambium layer (Sargent 1995). In vertebrate-dispersed mistletoes developing larger haustorial disks a lower limit may be set by the capacity of the branch to serve as bird perches and/or to sustain the infection by a large nutrientdiverting haustorial system (Sargent 1995, Watson 2001, Restrepo et al. 2002).

\section{Dynamics of vegetative reproduction}

Misodendrum punctulatum commonly renews aerial shoots based on a localized infection system (Calvin \& Wilson 1996). Similarly to Arceuthobium, the endophytic system disappears along the branch beyond a few centimeters from the initial infection point. When infections occur on main stems, typical triangle-shaped endophytic infections are visible in transversal stump cross-sections. Longevity of these endophytic systems is limited to $24 \mathrm{yr}$ (30 to 50 $\mathrm{mm}$ of radial growth on $N$. pumilio) after which the old system (as well as the associated aerial shoots) collapse and a new system is laterally formed from activated buds at the base of the host callus. As with other stem injuries (e.g., fire, or mechanical damage) callus tissue may eventually cover the entire scar surface leaving the dead endophytic system embedded in the stem latewood. This discrete event-like renewal of endophytic systems can recur several times in the lifetime of a tree. The collapse of each endophytic event may be triggered by signals related to the loss of hydraulic conductivity while haustoria become gradually imbedded in non-functional latewood xylem.

This is to our knowledge the first reported case of mistletoe infections on adult host stems based on this unique re-infection system rather than systemic infection from branches. Classic vegetative reproduction in mistletoes is generally related to systemic and non-systemic epicormic sprouting of new shoots (Calvin \& Wilson 1996) in response to internal hormonal signals as well as external factors such as pruning and fire (Kelly et al. 1997). Here we report a new system of vegetative reproduction based on the death and renewal of the entire endophytic and aerial shoot system that ensures longevities of mistletoe individuals of $>100 \mathrm{yr}$. However, continuous exposure of open scars of most recent re-infections promotes the entry of fungi, pathogens and insects (Cwielong \& Rajchenberg 1995) that in the long run may reduce host stem physical resistance.

Embedding of endophytic structures within annual tree-ring producing hosts offers the opportunity to understand key life history features and demographic processes of higher parasitic plants that may otherwise be overlooked. Future systematic analyses of timedependent processes on wider arrays of parasitic species may help further understanding of how this diverse and complexly evolved functional group persists in so many environments and with such diverse interactions with their hosts.

\section{ACKNOWLEDGMENTS}

The authors thank Gernot Vobis for advice and for providing access to the microtome equipment; Marcelo Aizen for comments on the manuscript and Mariana Tadey for the drawing of Figure 2. This research was financed by Red Latinoamericana de Botánica for a fellowship RLB-99M1 to NT-B; Agencia Nacional de Promoción Científica y Tecnológica (ANPCyT), Argentina for grant PICT 97-01-02268 to TK; TK is a researcher for the Consejo Nacional de Investigaciones Científicas y Tecnológicas (CONICET), Argentina.

\section{LITERATURE CITED}

AGRIOS GN (1969) Plant Pathology. Academic Press, New York, New York, USA. 656 pp.

AMICO GC (2000) Dispersión del quintral (Tristerix corymbosus) por el monito del monte (Dromiciops australis). BSc Thesis, Universidad Nacional del Comahue, Bariloche, Argentina. 63 pp.

AMICO GC \& MA AIZEN (2000) Mistletoe seed dispersal by a marsupial. Nature 408: 929-930.

CALDER DM (1983) Mistletoes in focus: an introduction. In: Calder DM \& P Bernhardt (eds) The biology of mistletoes: 1-17. Academic Press, Sydney, Australia.

CALVIN CL (1967) Anatomy of the endophytic system of the mistletoes Phoradendron flavescens. Botanical Gazette 128: 117-137.

CALVIN CL \& CA WILSON (1996) Endophytic system. In: Hawksworth FG \& D Wiens (eds) Agriculture handbook 709. Dwarf mistletoes: biology, pathology, and systematic. United States Department of Agriculture Forest Service, Washington, District of Columbia, USA. Electronic version in: http:// www.rmrs.nau.edu/publications/ah709

CWIELONG PP \& M RAJCHENBERG (1995) Forma de ataque y daños provocados por Misodendrum punctulatum en lenga. Actas IV Jornadas Forestales Patagónicas: 56-66. San Martín de los Andes, Argentina.

DAWSON TE \& JR EHLERINGER (1991) Ecological correlates of seed mass variation in Phoradendron juniperinum, a xylem-tapping mistletoe. Oecologia 85: 332-342.

DAWSON TE, J KING \& JR EHLERINGER (1990) Age structure of Phoradendron juniperinum (Viscaceae), a xylem-tapping mistletoe: inferences from a non-destructive morphological index of age. American Journal of Botany 77: 573-583. 
ELHERINGER JR, ED SCHULZE, H ZIEGLER, OL LANGE, GD FARQUHAR \& IR COWAN (1985) Xylem-tapping mistletoe: water or nutrient parasites? Science 227: 1479-1481.

FISHER JT (1983) Water relations of mistletoes and theirs hosts. In: Calder DM \& P Bernhardt (eds) The biology of mistletoes: 161-183. Academic Press, Sydney, Australia.

HARPER JL (1977) Populations Biology of Plants. Eighth edition. Academic Press, Oxford, United Kingdom. 892 pp.

HAWKSWORTH FG (1961) Dwarf mistletoes on ponderosa pine in the southwest. United States Department of Agriculture, Forest Service, Washington, District of Columbia, USA, Technical bulletin $1246.112 \mathrm{pp}$.

HAWKSWORTH FG \& D WIENS (1996) Dwarf mistletoes: biology, pathology, and systematics. United States Department of Agriculture Forest Service, Washington, District of Columbia, USA Agriculture Handbook 709. Electronic version: http://www.rmrs.nau.edu/publications/ah_709/

HERRERA CM (1987) Vertebrate-dispersed plants of the Iberian Peninsula: a study of fruit characteristics. Ecological Monographs 54: 305-331.

KELLY P, N REID \& I DAVIES (1997) Effect of experimental burning, defoliation, and pruning on survival and vegetative resprouting in mistletoes (Amyema miquelii and Amyema pendula). International Journal of Plant Science 158: 856-861.

LADLEY JJ \& D KELLY (1996) Dispersal, germination and survival of New Zealand mistletoes (Loranthaceae): dependence on birds. New Zealand Journal of Ecology 20: 69-79.

LAMONT B (1983) Germination of mistletoes. In: Calder M \& P Bernhardt (eds) The biology of mistletoes: 31-143. Academic Press, Sydney, Australia.

LaMARCHE VC JR, RL HOLMES, PW DUNWIDDIE \& LG DREW (1979) Tree-ring chronologies of the southern hemisphere. Chronology series V. Laboratory of tree ring research, University of Arizona, Tucson, Arizona, USA. 77 pp.

LICHTER JM \& AM BERRY (1991) Establishment of the mistletoe Phoradendron macrophyllum: phenology of early stages and host compatibility studies. Botanical Gazette 152: 468-475.

MARTÍNEZ DEL RÍO C, A SILVA, R MEDEL \& M HOURDEQUIN (1996) Seed dispersers as disease vectors: bird transmission of mistletoe seeds to plant hosts. Ecology 77: 912-921.

MANION PD (1991) Tree disease concepts. Prentice-Hall, Englewood Cliffs, New Jersey, USA. 416 pp

NORTON DA, J LADLEY \& AD SPARROW (1997) Development of non-destructive age indices for three New Zealand loranthaceous mistletoes. New Zealand Journal of Botany 35: 337-343.

ORFILA EN (1976) Sinopsis de las Misodendraceae de la Argentina y Chile. Revista de la Facultad Agronomía Universidad de La Plata 52: 37-62

ORFILA EN (1978) Misodendraceae de la Argentina y Chile. Fundación Elías y Ethel Malamud, Buenos Aires, Argentina. $73 \mathrm{pp}$

REID N, M STAFFORD SMITH \& Z YAN (1995) Ecology and population biology of mistletoes. In: Lowman MD \& NM Nadkarni (eds) Forest canopies: 285-310. Academic Press, Orlando, Florida, USA.
RESTREPO C, S SARGEN, DJ LEVEY \& DM WATSON (2002) The role of vertebrates in the diversification of new world mistletoes. In: Levey DJ, WR Siva \& M Galetti (eds) Seed dispersal and frugivory: ecology, evolution and conservation: 83-98. CAB International, Cambridge, Massachusetts, USA.

ROSSOW RA (1982) Sinopsis de las Misodendraceae. Parodiana: 245-270.

SARGENT S (1995) Seed fate in a tropical mistletoe: the importance of host twig size. Functional Ecology 9: 197-204.

SCHARPF RF \& JR PARMETER (1976) Population buildup and vertical spread of dwarf mistletoe on young red and white firs in California. Pacific Southwest Forest and Range Station, Forest Service, United States Department of Agriculture, USA. Paper PSW-122: 1-9.

SCHARPF RF \& JR PARMETER (1982) Population dynamics of dwarf mistletoe on young true firs in the central Sierra Nevada, California. Research Paper PSW-161. Forest Service, United States Department of Agriculture, USA. 9 pp.

SCHULMAN E (1956) Dendroclimatology in the Patagonian Andes. In: Schulman E (ed) Dendroclimatic changes in semiarid America: 125135, University of Arizona Press, Tucson, Arizona, USA.

SHAW CG \& EM LOOPSTRA (1991) Development of dwarf mistletoe infections on inoculated western hemlock trees in south east Alaska. Northwestern Science 65: 48-52.

SILVA A \& C MARTÍNEZ DEL RÍO (1996) Effects of the mistletoe Tristerix aphyllus (Loranthaceae) on the reproduction of in cactus host Echinopsis chilensis. Oikos 75: 437-442

SRIVASTAVA LM \& K ESAU (1961) Relations of dwarf mistletoes (Arceuthobium) to xylem tissue of conifers. I. Anatomy of parasite sinkers and their connections with host xylem. American Journal of Botany 48: 159-167.

TERCERO-BUCARDO N (2001) Dinámica de infección por Misodendrum punctulatum en bosques caducifolios de Nothofagus del noroeste de la Patagonia: dispersión, establecimiento y efecto de las hemiparásitas; susceptibilidad del hospedador. MSc. Thesis, Universidad de Buenos Aires, Argentina. $146 \mathrm{pp}$.

VEBLEN TT, C DONOSO, T KITZBERGER \& AJ REBERTUS (1996) Ecology of Southern Chilean and Argentinean Nothofagus forests. In: Veblen TT, RS Hill \& J Read (eds) The ecology and biogeography of Nothofagus forests: 293-353. Yale University Press, New Haven, Connecticut, USA.

WAGENER WW (1962) Dwarf mistletoe incubation period on Ponderosa and Jeffrey pines in California. Forest Science 8: 16-20.

WATSON DM (2001) Mistletoe - a keystone resource in forest and woodland worldwide. Annual Review of Ecology and Systematics 32: 219-249

WILLIS JC (1973) A dictionary of the flowering plants and ferns. Cambridge University Press, Cambridge, United Kingdom. 1236 pp.

YAN Z (1993) Germination and seedling development of two mistletoes, Amyema preissii and Lysiana exocarpi: host specificity and mistletoes-host compatibility. Australian Journal of Ecology 18: 419-429. 